\title{
Meta
}

Journal des traducteurs

Translators' Journal

\section{India, England, France: A (Post-) Colonial Translational Triangle}

\section{Harish Trivedi}

Volume 42, numéro 2, juin 1997

Lexicologie et terminologie II (1) et Traduction et post-colonialisme en Inde

Translation and Postcolonialism: India (2)

URI : https://id.erudit.org/iderudit/004510ar

DOI : https://doi.org/10.7202/004510ar

Aller au sommaire du numéro

Éditeur(s)

Les Presses de l'Université de Montréal

ISSN

0026-0452 (imprimé)

1492-1421 (numérique)

Découvrir la revue

Citer cet article

Trivedi, H. (1997). India, England, France: A (Post-) Colonial Translational Triangle. Meta, 42(2), 407-415. https://doi.org/10.7202/004510ar
Résumé de l'article

En 1923, le célèbre romancier et nouvelliste indien Premchand faisait paraître sa traduction, en hindi, du roman d'Anatole France Thaïs - traduction très proche de l'original mais volontairement libérale par endroits. Le choix de cette œuvre constitue un geste politique délibéré. Traduire un texte ne faisant pas partie du répertoire de la puissance colonisatrice, c'était en quelque sorte chercher à libérer la littérature de sa tutelle. D'autres traducteurs allaient poursuivre dans cette voie, avant et après l'indépendance, dévoilant ainsi les horizons plus vastes d'un univers non colonial, non britannique en l'occurrence.
Ce document est protégé par la loi sur le droit d'auteur. L'utilisation des services d’Érudit (y compris la reproduction) est assujettie à sa politique d'utilisation que vous pouvez consulter en ligne.

https://apropos.erudit.org/fr/usagers/politique-dutilisation/ 


\title{
INDIA, ENGLAND, FRANCE: A (POST-)COLONIAL TRANSLATIONAL TRIANGLE
}

HARISH TRIVEDI

University of Delhi, Delhi, India

\begin{abstract}
Résumé
En 1923, le célèbre romancier et nouvelliste indien Premchand faisait parâtre sa traduction, en hindi, du roman d'Anatole France Thaïs - traduction très proche de l'original mais volontairement libérale par endroits. Le choix de cette ceuvre constitue un geste politique délibéré. Traduire un texte ne faisant pas partie du répertoire de la puissance colonisatrice, c'était en quelque sorte chercher à libérer la littérature de sa tutelle. D'autres traducteurs allaient poursuivre dans cette voie, avant et après l'indépendance, dévoilant ainsi les horizons plus vastes d' un univers non colonial, non britannique en l'occurrence.
\end{abstract}

\begin{abstract}
In 1923 appeared the translation into Hindi by Premchand, the celebrated Indian novelist and short-story writer, of Anatole France's Thais. The production and publication of this translation, a close but not blindly faithful version, was a distinctly political act: the choice of a text not part of the literature of the colonial power constituted an attempt towards the liberation of Indian literature from the tutelage of the imperially-inducted master literature, English. This gesture was repeated by other translators during both the pre-Independence and post-Independence periods, as they reached out to the wider, and for India, non-colonial, i.e. non-British, world.
\end{abstract}

"In Europe, the delightful literature of France is the best of all."1 So began the translator's "Introduction" to a Hindi version published in 1923 of Anatole France's novel Thaïs (1890). The high opinion of French literature so confidently proclaimed here was offered by the translator not as a personal preference but as a truth universally acknowledged, and its axiomatic quality was reinforced in the original Hindi phrasing through the pithiness and insistent alliteration of what was apparently a carefully premeditated opening dictum: "Europe men France ka sarasa sahitya sarvottam hai." Also notable was the use of the word sarasa, which has the connotations not quite contained in 'delightful', either in such cheapened usage as 'how delightful' or even, for example, in Dr Johnson's more strictly aesthetic sense in the classical formulation that the function of literature is to delight and to instruct. Sarasa in Hindi (and Sanskrit) means that which has rasa, i.e. 'juice', both in the sense of sap which sustains life and that which is (in that suggestive adjective) 'juicy'. Moreover, rasa is of course a key word in Sanskrit poetics, where it means any of the eight (or, variantly, nine) basic sentiments or emotions which a writer invests his writing with and whose enjoyment in turn by the sympathetic reader constitutes the proper appreciation of literature. ${ }^{2}$

The Hindi translator offering such unstinting and apt praise of French literature was no mean or mere translator but in fact a writer indisputably acknowledged to be the greatest novelist yet in Hindi, Premchand (1880-1936). Before this translation, he had published six novels and over one hundred short stories of his own in both Hindi and Urdu. From 1900 to 1921 , he had served as a schoolmaster, headmaster, and sub-deputy inspector of 
schools, until he resigned government service in answer to Gandhi's call at a public meeting which he attended, to non-cooperate with the British. Meanwhile, early in his writing career, the first collection of his short stories, Soz-e-Vatan (1907: The Dirge of the Nation), which he had anyhow published under a pseudonym, had been proscribed by his British superior officer as being "full of sedition." (Rai 1982: 74) At the time of translating France, Premchand was about to enter the last great phase of his career, in which he produced two epic nationalist novels, Rangabhumi (1925: The Playground/Stage) and Karmabhumi (1932: The Field of Action), and his magnum opus, Godan (1936: The Gift of a Cow), which is probably the greatest novel ever written about the poverty and misery of rural India not only in Hindi but in any language. Like many major Hindi (or indeed Indian) writers of his generation, Premchand contributed to Hindi literature not only through his own original writings but also through translating into it great and congenial works from world literature. He knew English very well, having studied it as one of his subjects through school and right up to the B.A., but no other foreign language, and all his translations of works of Western literature were done from translations available in English. ${ }^{3}$

While it is well-worth examining Premchand's choice of Thaïs as a text to translate and the specific details of his practice in translating it, it may be equally of interest to place this act of translation in the wider historical context of a crucial turbulent phase of our colonial history. I seek to show in this paper that the historical moment of Premchand's translation of France imparted it an extra-literary charge which turned it, among its other virtues, also into a small gesture towards the liberation of Hindi (and Indian) literature from the tutelage of the imperially-inducted master literature, English.

\section{I}

Following the institution of English education in India, officially legislated for in the 1830s but effectively introduced only from the 1850 s, a number of eighteenth-century classics of English literature were translated into Indian languages. As if in a counteracting compensatory activity, an equally large number of Sanskrit texts were also translated into the modern Indian languages at this time, often by the same multilingual translators (Trivedi 1995: 176-198), but, as yet, hardly any works from other Western languages. It was only in the early decades of the twentieth century that Indian translators began to go beyond, behind and around texts from English literature in order to reach out to works from other languages. A patent stimulus here was the newly instituted Nobel prize; it seems to have afforded non-English writers a level of visibility and circulation (mainly through English translation) which they otherwise might not have achieved. The Indian regard for the Nobel was considerably reinforced after an Indian won it in 1913, the Bengali poet Rabindranath Tagore. Thus, in its wake, Premchand himself translated into Urdu under the title Shab-e-Tar (1919) the play Les aveugles (1890: English translation by L. A. Tadema, 1895) by the Belgian writer Maurice Maeterlinck, following the award of the Nobel to him in 1911, and he published commissioned translations of three plays by John Galsworthy in 1933, upon his having won the Nobel the previous year.

The globalization of the Indian literary scene through awareness generated by the Nobel prize also served in some ways to place English literature in perspective. In the first twenty years of the award, 1901-1920, only one English writer had won it, Kipling, and over the following twenty years, 1921-1940, just three more were to win it, Yeats, Shaw and Galsworthy. The sense of a universal supremacy of English literature, assiduously fostered in India under imperial aegis, was seriously modified, and several non-English literatures were now seen in a comparative light which was far from flattering to English 
literature. It now seemed to be part of a new spirit of literary independence to welcome through translation non-English writers into the Indian languages, and Premchand's acclaim of French literature is in consonance with this general phenomenon of discovery and assimilation.

But in this particular case, there was an additional factor which apparently attracted Premchand strongly towards this text, and that was its special affinity, as he perceived it, with Indian values and Indian sensibility. Throughout his "Introduction," Premchand used Hindi/Sanskrit words loaded with traditional Indian/Hindi cultural values to express his admiration for this novel. In the very first paragraph, for example, he said that Thais represents a unique blending together of "satyam, shivam, sundaram," i.e. the three hallowed virtues of "the true, the good, and the beautiful." (Premchand 1923: 1) He described a character called Palémon, in the Hindi version named Palam, as a devotee of ahimsa, or non-violence, as lately advocated and valorized by Gandhi as a means of resistance against the British. He saw another character, St. Antony, as being similar to the rishis, or divinely-inspired sages in our own tradition, and he found a particular speech by Thaïs, which he here quoted from, as being "full of bhakti," or religious devotion as practised in Hinduism (Premchand 1923: 1, 2,7).

Above all, however, he found a persistent parallel in Indian mythology to what in his view was the theme of this novel, the egotism or pride, and the consequent fall, of a holy man:

In our holy books, too, we find tales of the fall due to vanity of rishis, but their origin lies in the sensual desires of the rishi. The rishi grows proud of his asceticism. To smash his pride Lord Vishnu weaves a web of maya [illusory beguilement] around him, and the rishi soon comes to his senses. (Premchand 1923: 30)

In accordance with such an interpretation of the novel, Premchand decentred France's sensuous heroine from the title of the novel and called his version Ahankara (egotism/ vanity/pride) as manifested by its ascetic hero. As in the title so too throughout his translation, Premchand highlighted the spiritiual strand of the story, as it related to the hero, rather than the erotic sensuous quality as embodied in the heroine, which latter seemed to have been rather more in focus in France's original version; France was, indeed, sometimes described as a juicy or "bawdy" writer and in the case of Thaïs in particular, as even "mildly pornographic." (Thorlby 1969: 279) In his translation, on the other hand, Premchand reinforced the spiritual aspect of the novel by using effectively the Hindi vocabulary of spiritualism, by making some small additions both in the text and in one or two footnotes, and by touching up here and there or even insinuating on his own the superiority of the Indian spiritual tradition over that expressed in the novel.

Though Premchand affirmed in his "Introduction" that he was a "sworn opponent" of the practice of adaptation by which only the main plot was followed in the translation but all the incidental details changed - "for that would be as if someone were to eat only the chapatis on his plate but leave lentils, vegetables, pickle and chutney" (Premchand 1923: 80), he did modify and Indianize some proper names while broadly adhering to the original sounds. The most important of these changes again served to underline the spirituality of the story. The name of the hero, Paphnuce in the original (and Paphnucius in the English translation by R. B. Douglas, 1909, which Premchand presumably used as his source text), was turned into Papnashi, which in Hindi acquires the bonus of being a word with a readily understood meaning, i.e., the Destroyer of Sins! Premchand further exploited this gain in significance when he renamed the new holy city which by France is called "Stylopolis" as Papmochan, i.e., that which releases or delivers one from sins (France 1890: 211; Premchand 1923: 144); he explained that it was named after the hero, which 
of course it is not in the original. There is possibly a local allusion here as well, for, in the holy Hindu city of Benares / Varanasi, which was Premchand's home, a major temple dedicated to Lord Hanuman is called "Sankatmochan" ("He who delivers one from crises or disasters").

In his translation Premchand also made several changes or modifications which serve to juxtapose the Christian spirituality depicted in this novel with Indian spirituality, or even to show the former up against the latter. Early in the novel, Paphnuce pulled down a hood over his head and eyes in an act of self-denial so that he would not be distracted by the surrounding beauties of nature. Premchand here added: "On the contrary, Indian sages and great men were given to taking delight in the beauty of nature" (France 1890: 22; Premchand 1923: 20). A little later, an old man whom Paphnuce met narrated to him his own life-story of spiritual quest, during which he had travelled to Italy, Greece and Africa, and finally arrived in India, where he had seen a naked man who had been sitting still with his legs crossed for thirty years. Premchand here supplied the technical Sanskrit term for sitting in that pose, padmasana, and properly called this man a yogi, which France had not (France 1890: 32; Premchand 1923: 26). In a scene in which Paphnuce tried to persuade Thaïs to enter a Christian monastery, he looked at her at a particular moment avec bonté (France 1890: 156), while Premchand went a bit further to translate this phrase as "snehmay karuna se," i.e., with affectionate compassion, the Hindi / Sanskrit word here used for compassion, karuna, being the same as traditionally used for the Hindu gods as well as for the Lord Buddha (Premchand 1923: 103). On another occasion, when Cotta incredulously wondered at Paphnuce having stayed atop his high column without setting foot on ground for a whole year, Aristée/Aristius reminded him of "les gymnosophistes de l'Inde" who could remain entirely immobile "non point seulement le long d'une année, mais durant vingt, trente et quarante ans" (France 1890: 213). In his translation, Premchand again used the word "yogis" for "gymnosophistes," and went on where France left off to add off his own bat:

Indeed, sometimes for much longer than that. In fact, what I have heard is that they can stay in samadhi [spiritual trance] without food or water for even a hundred years at a time. (Premchand 1923: 146)

Such a clear assertion of Indian spiritual superiority over any competition from the West may now seem to be itself naively complicit in orientalism, but it was during the colonial period well recognized as a strategy of cultural-nationalist resistance. In any case, there was exotic orientalism enough in France's original text, which Premchand, to his credit, neither erased nor mitigated. Amidst much Egyptian, Iranian and other settings and paraphernalia, France also introduced as part of the sumptuous household of Thais four Indians who are in charge of her kitchen and each one of whom is one-eyed. It had been a sport of Thaïs to collect four such men of the same race and with the same physical defect, and at her grand feasts they excited the curiosity of her guests and served as a conversation piece while Thaïs had each of them narrate his respective life-story. In his version, Premchand retains this piece of racist, orientalist grotesquerie with no change or comment, except silently to correct France on one point of racial detail. France had said, improbably, that these Indians had "la peau jaune" (France 1890: 161) but Premchand modified this to "sanwale rang ke," i.e., of a dusky complexion (Premchand 1923: 107).

Elsewhere too in his translation, Premchand did not feel inhibited from accomodating the foreign text to the Indian cultural context in a number of small ways. He replaced unfamiliar musical instruments in Thaïs' house with the very Indian "sarod, sitar, veena" (Premchand 1923: 109 and also 30, 95, 165); in describing the ravishing Thaiis he resorted to terms traditionally employed in the Indian languages to evoke superlative beauty, thus 
describing her face once as "mukhkamal" (lotus-face) and elsewhere repeatedly as "mukhchandra" (moon-face), going even further once to elaborate on this trope. For "la douleur était belle sur le visage de Thails" he substituted "Thails' moon-face had in this state of grief become even sweeter, as does the moon when lightly covered by a cloud" (France 1890: 63; Premchand 1923: 44).

More important to the theme perhaps was Premchand's deployment at many places of the words shringar and vairagya (love and renunciation), which constitute a familiar polarity in Sanskrit poetry (as famously in the century of verses each by the poet Bhartihari on these themes). On occasion, Premchand also evoked the Hindu religious concepts of re-birth and of maya, i.e. the world as illusion (Premchand 1923: 98, 130). And, in one instance, in that grand setpiece, the banquet scene, Premchand provided a detailed parallel from the ancient Indian epics to elaborate on a moral statement made in the text. In France, in the prolonged philosophical debate which forms the core of this scene, Zénothémis argues that it was quite necessary for the divine plan to unfold and for the doctrine of redemption to be founded that Judas Iscariot should have accepted his thirty pieces of silver. In a footnote here, Premchand adduced the instances of two similarly maligned Indian characters, Kaikeyi from the Ramayana (who asked for Lord Rama's banishment) and Duryodhana from the Mahabharata (who publicly disrobed Draupadi), to illustrate the axiom that good comes out of bad (France 1890: 143; Premchand 1923: 95n).

Premchand's Ahankar then is a close but not blindly "faithful" version of France's Thaïs. Without altering the text in any substantial or significant way, he foregrounded from time to time the target-language cultural context, and he did so with notable ease and native assurance. His reinforcement of the spiritual aspect of the story underlined its suitability and congeniality for its new Hindi/Hindu readership. Incidentally, this was further strengthened by the presence in France's novel of repeated thrusts against fanatical Christianity, the religion which of course was aggressively and determinedly sought to be promoted in India by English and other missionaries during British rule, though not to any great avail. In France's novel, too, the depiction of Christianity is far from prepossessing. Indeed, as one critic has pointed out, the function of Thais in the novel is to offer a critique of "the restricted ascetic vision of the [Christian] monk." She is shown as part Alexandrian and part Greek and we see her first in the novel as enacting the role of the Greek Polyxena, and thus, through her, "the retreating civilization of Greece [...] wins an important rear guard action against the fanaticism of early Christianity" (Walton 1950: 231-232).

Altogether, in translating this novel, Premchand seems to have gone beyond the restrictive parameters of English literature to access a foreign text, which was the more congenial to him for being in his view superior to English texts. Apropos the superb characterization of Thaïs herself, which Premchand found to be "as acute as it is enchanting," he went on to generalize: "French novelists have a special flair for depicting female characters" (Premchand 1923: 5). But it was towards the end of his "Introduction" that he stated most forthrightly - and invidiously - the comparative superiority of this text for him:

We have translated this [book] for the sole reason that it appeared to us to be excellent in every respect, and we do not hesitate to say that we have not seen a better literary work in English. (Premchand 1923: 8)

Indeed, Premchand's choice of his translated text showed, as do translations from very different contexts, "how cultural exchange is nourished by individual desires and infatuations, just as it feeds on the tensions of historical relationships" (Simon 1995: 7-8). 


\section{II}

This outright judgement was not the only instance of Premchand's assertion of the superiority of French literature over the English. In a series of three essays on "Kahni Kala" (The Art of Fiction), he said:

... in my view, short stories of a higher quality are to be found in the French and Russian literatures than in any other European language. In English, too, Dickens, Wells, Hardy, Kipling, Charlotte Yonge and Brontë [sic] etc. have written short stories, but they cannot stand comparison with the creations of Guy de Maupassant, Balzac or Pierre Loti. French short stories are extremely delightful. Besides, Maupassant and Balzac have not let go of the ideal [of moral teaching] behind story-telling; they always try and resolve some social or spiritual problem. (Premchand 1923: 27-28)

Nor was Premchand alone in showing such a francophile tendency. In fact his translation of Thais had a fall-out as spectacular as it must have been unexpected. A younger Hindi novelist, Bhagvati Charan Verma (1903-1981), seems to have read it and been inspired to write a novel, Chitralekha (1935), which bore a broad thematic similarity to Thaïs / Ahankar, though it was distinct from it in plot, characters and even the moral of the tale. As a recent History of Hindi Literature puts it: "Some critics have found in Chitralekha a shadow of Anatole France's Thaïs. Verma himself has acknowledged the influence of Anatole France in writing Chitralekha. But it has its own independent form and organization" (Snatak 1996: 301). Verma's novel shows the eponymous heroine, who is a beautiful dancer but (unlike Thaïs) "not a courtesan" (Verma 1956: 2), engaged in a struggle for supremacy with the monk Kumaragiri. But the novel also has a third arm of the triangle in the young pleasure-loving aristocrat Beejgupt (of whom the merest hint exists in France's Nicias perhaps?), to whom Chitralekha is equally attracted. The novel concludes by stating that neither the hedonist Beejgupt nor the fallen monk Kumaragiri is a sinner, for the good karmic reasion that "there has never been [just] one definition of sin, and never will be. We have neither vice nor virtue, we only do what we have to..." (Verma 1956: 159). This historical-fictional staging of a philosophical battle between the principle of pleasure on the one hand and spiritual abstinence on the other, with Chitralekha herself playing not a decorative and passive but a vigorously articulate and even dominant role, proved immensely popular in Hindi. The novel has sold and sold, become a set-book in college syllabi, been made into a successful Hindi film, and been translated into English. However, it is a little paradoxical that what is taken by many of its Hindi readers to be a quintessentially Indian philosophical allegory should have had its donnée in what is after all a minor French novel.

Besides France, several other French writers were rendered into Hindi over the first half of this century, in the period leading up to independence. Among the most popular of these perhaps were Molière, Dumas, Hugo and Maupassant. Again, these authors were often acclaimed by their respective translators, as was France by Premchand, not only as being great French writers but also as being better than any other writers in the world. To take just one example, Dumas' La tulipe noire appeared in two different Hindi translations, both of which were highly successful and were more than once reprinted. Pandit Siddhagopal translated the novel from the original French in 1932, making in his preface an explicit and levelling comparison between French and English literatures: "The best writers of France are Victor Hugo and Alexander Dumas. As a historical romancer, Dumas is regarded as the equal of the famous English novelist Sir Walter Scott"' (Siddhagopal 1932: n.p.). The other translation was by Rishabh Charan Jain, who declared in his preface that he was willing to sing paeans to the greatness of Dumas from the roof-tops. In his translation of another work by Dumas, in English titled The Queen's Necklace, the same 
translator stated in his preface: "I do not know much of foreign literature but on the basis of what I do know, I regard Dumas as the best of all novelists" (Jain 1953: n.p.). Similar praise was conferred by more than one translator also on Molière, whose kind of farcical comedy was found to be deliciously new in Hindi. Many of Molière's plays continue to be translated, staged and broadcast on TV in Hindi, with the most popular perhaps being Tartuffe, with its theme of sensualist/ascetic duality or hypocrisy, and Le bourgeois gentilhomme, with its satire on attempts quickly to acquire culture and sophistication.

Following the coming of independence in 1947, France assumed if anything an even more important place for Hindi writers now looking to explore world literature on their own terms. For some reason, the French symbolist poets were widely translated in the 1950s, in the Hindi journal Yug-chetna, for example, perhaps in the wake of the wide popularity of T.S. Eliot's kind of modernism which had itself been influenced by the French symbolists. A little later, in the 1960s and 1970s, French existentialism was embraced by Hindi writers as being the most avant-garde of all literary movements then prevalent in the world, and as certainly more exciting and stimulating than anything being produced in old England.

An early translation here was Ajnabi (1961: The Stranger) by one of the most distinguished exponents of the "New Short Story" in Hindi, Rajendra Yadav (1929-). Since then, Camus has perhaps become the most extensively translated of the modern French writers into Hindi, through the dedicated efforts of just one individual, Sharad Chandra, who has translated him direct from the French and is also the author of a book titled Camus and India, in which she argues that Camus was familiar with many key works of Vedanta philosophy and had an "intellectual affinity" with India, while he also influenced in turn a number of contemporary Hindi poets and novelists (Chandra 1991: $31 \mathrm{ff}$.). In terms of influence, Sartre perhaps was an even larger figure at this time, though he was not extensively translated into Hindi. In any case, the word "santras" (angst) became one of the buzz words of the Hindi literary scene in the 1960s and 1970s, to the extent of inviting the charge that much of it was in fact "orha hua santras," i.e. put on angst, and not the genuine existentialist article.

This extremely sketchy account of the reception of French literature in Hindi represents not an isolated phenomenon but part of a wider pan-Indian development which took place fairly simultaneously in many other Indian languages. To give just a couple of random examples, when the first Department of Comparative Literature was founded in India at Jadavpur University in 1956, partially in an attempt to challenge the continuing primacy of the English Departments in the country, it leant rather more heavily towards French literature than even towards the local Bengali literature. Its founding head, the poet Buddhadeva Bose had a Ph.D. on Baudelaire from the Sorbonne and had translated into Bengali Baudelaire, Mallarmé and Rimbaud. A contemporary Marathi poet, Dilip Chitre, has similarly translated these same poets into his language, and is apparently quite happy being described as "the leading French poet practising in Marathi," because, as he himself explains, "my concept of poetry is French" (Ramakrishnan 1995: 232).

For Hindi literature, which hasn't known such excesses as cited above in Bengali or Marathi, its whole French connection has been a liberating attempt to go beyond the colonial dominance of English literature without swinging to the other extreme or toppling over. It has been part of an endeavour to reach out to the wider (for us) non-colonial world out there. Often, as seen above, a French text has been used by a Hindi translator as a kind of stick with which to beat English literature; in these cases (if one were to use the source language/target language phraseology), a non-canonical text has been sourced in order to target the colonial canon.

Such an adverserial polarity between the English and the French was, of course, not a new phenomenon either in the history of these two nations or even in the modern history 
of India. After the initial false starts by the Portuguese and the Dutch, there had followed in India, through much of the eighteenth century and well into the nineteenth, a battle for colonial supremacy between the French and the English. The French were probably at their strongest in India under the governorship from 1742 to 1754 of Joseph François Dupleix (1697-1764). But as late as 1799, Napoleon himself was writing to Tipu Sultan promising help in his wars against the British; it was against a native Maratha force "commanded by M. Louis Bourquien," a French general, that the British won in 1803 "the battle of Delhi," following which the Mughal emperor became their pensioner; and it wasn't really until 1815 and the defeat at Waterloo that the possibility of a French empire in India disappeared for good. As token reminders of this history, the little pocket of Chandernagore (near Calcutta), which passed and repassed between the French and the English at least six times between 1757 and 1815, and the somewhat larger possession of Pondicherry (near Madras /Chennai), which harboured anti-British political refugees such as the poets Aurobindo Ghosh and Subramania Bharati, both remained under French rule till 1951, not only right throughout the period during which the British ruled India but in fact for four years after they had quit. Meanwhile, during the nationalist movement, India had acquired a high-profile French writer and Nobel-prize winning internationalist, Romain Rolland (1866-1944), as a sympathtic champion. Rolland was a friend of Tagore and Gandhi and the author of biographies of Gandhi (1924), of the religious nationalist leader Vivekananda (1930), and of the latter's guru, the mystic Ramakrishna (1929). Interestingly, Rolland's extensive diary entries relating to India have been translated into Hindi in two volumes with the sponsorship of the government of independent India: they are eulogized in a preface as being "a living document of India's vigour, dignity and greatness" (Rolland 1984: n.p.).

Though it will be possible to construct a similar account of the Hindi reception of some European literatures other than the French, especially of the Portuguese, the German and the Russian, it is, for some of the considerations indicated above, likely to be not half as extensive or significant. After English literature, the literature which most Indian languages have had most to do with has been the French, ${ }^{5}$ for reasons that are not only universally aesthetical (e.g. "France's reputation as mother of the arts;" Zeldin 1983: 364) but also specifically historical and political. Due to this context, the appreciation and appropriation of French literature by Hindi (/Indian) writers, translators and critics has sometimes carried the sub-text of an anti-English thrust. The reception of French literature in India may not always have carried a whiff of subversion against English literature, but it has nearly always provided a necessary and salutary supplementarity to it, and helped to put English literature in its place so that while it continued to be dominant it did not become altogether stifling. If French literature was quite so delightful and excellent as Premchand declared it to be, and if he decided to translate Thaits because he had never come across a superior text in English literature, it did not merely indicate that Premchand liked French literature a lot; it was also meant to show that he liked English literature rather less, and possessed a comparative yardstick for measuring it up.

\section{Notes}

1. All translations from Hindi in this essay are mine, except where otherwise indicated.

2. For a would-be post-colonial exposition of this term, see Bill Ashcroft et al., The Empire Writes Back.

3. All the details of Premchand's life and career are taken from the standard prize-winning biography by Amrit Rai, except the date of publication of his translation of Thais, which it does not mention. This is confirmed as being 1923 by Kesavan and Mulay, p. 152, as well as by Madan Gopal, p. 189.

4. Inscription on the Victory Tower erected to commemorate the British military victory on 11 September 1803 in the Battle of Delhi. 
5. At least two Indian writers have written some of their works in French: the Bengali poet Michael Madhusudan Dutt (1824-1873), who had a French wife and lived for some time in Versailles, and the Indo-Anglian poet Toru Dutt (1856-1877), born in France, who published a volume of her poems in French, a volume of translations into English titled $A$ Sheaf Gleaned in French Fields (1876), and whose novelistic journal written in French has been translated into Hindi as "an Indian [Hindi?] homage" to her (Dutt 1879: 7). Of contemporary Indian writers, the novelist Raja Rao (1909-) was educated in Montpellier and at the Sorbonne, and lived for several years in France; the country figures prominently in his major novel The Serpent and the Rope (1960).

\section{REFERENCES}

ASHCROFT, Bill, GRIFFITHS, Gareth and Helen TIFFIN (1989): The Empire Writes Back, London, Routledge. CHANDRA, Sharad (1991): Camus and India, New Delhi, National Publishing House.

DUTT, Toru (1879/1969): Diary [a novel], Trans. into Hindi by Omar Sharad, Allahabad, Abhivyakti Prakashan. FRANCE, Anatole (1890; rpt. n.d.): Thais, Paris, Calmann-Levy.

GOPAL, Madan (1964): Munshi Premchand: A Literary Biography, Bombay, Asia Publishing House.

JAIN, Rishabh Charan (n.d.; 2nd impr. 1953): Quaidi [The Prisoner], Trans. of La tulipe noire by Alexandre Dumas, Delhi, Hindi Sahitya Mandal.

KESAVAN, B. S. and Y. M. MULAY (Eds) (1966): The National Bibliography of Indian Literature, 1901-53, vol. II, New Delhi, Sahitya Akademi.

PREMCHAND (1923; rpt. 1992): Ahankar, Trans. of Thaïs by Anatole France, Jaipur, Saityagar.

PREMCHAND (1973): Kuchh Vichar [Some Thoughts], Allahabad, Saraswati Press.

RAI, Amrit (1982; rpt. 1991): Premchand: His Life and Times, Trans. from Hindi by Harish Trivedi, Delhi, Oxford University Press.

RAMAKRISHNAN, E. V. (1995): Making It New: Modernism in Malayalam, Marathi and Hindi Poetry, Shimla, Indian Institute of Advanced Study.

ROLLAND, Romain (1984): Romain Rolland ka Bharat [Romain Rolland's India], Vol. I: 1915-1928, vol. II: 1929-1943, Trans. from French by Satyanarayan Sharma, New Delhi, Poorvodaya Prakashan.

SIDDHAGOPAL, Pandit (1932, rpt. 1972): Kalakar Quaidi [The Artist Prisoner], Trans. of La tulipe noire by Alexandre Dumas, Delhi, Hindi Granth Ratnakar.

SIMON, Sherry (Ed.) (1995): Culture in Transit: Translating the Literature of Quebec, Montreal, Vehicule Press.

SNATAK, Vijayendra (1996): Hindi Sahitya ka Itihas [A History of Hindi Literature], New Delhi, Sahitya Akademi.

THORLBY, Anthony (Ed.) (1969): The Penguin Companion to Literature. Vol. II: European, Harmondsworth, Penguin Books.

TRIVEDI, Harish (1995): Colonial Transactions: English Literature and India, Manchester and New York, Manchester University Press.

VERMA, Bhagvati Charan (1956): Chitralekha, Trans. from Hindi by Chandra B. Karki, Bombay, Jaico Publishing House.

WALTON, Loring Baker (1950): Anatole France and the Greek World, Durham (N.C.), Duke University Press. YADAV, Rajendra (1961, rpt. 1983): Ajnabi, trans. of L'étranger by Albert Camus, New Delhi, Rajkamal. ZELDIN, Theodor (1983, rpt. 1987): The French, London, Fontana. 